\title{
Editorial
}

\section{A new chapter in public health: Britain's changing relationship with the European Union}

Eighteen months ago Britain's relationship with Europe in the field of public health was characterised by conflict, mistrust, and mutual recriminations. The BSE crisis was at its height and the British government had decided to mark its dissatisfaction with the European Union by refusing to cooperate on any policy, including those that it had initially proposed. The ban on the export of British beef remains, but much else has changed.

At a conference on public health in Europe held in London in May to mark the United Kingdom's presidency of the European Union, Tessa Jowell, the British minister for public health, spelt out why it is Britain's interests to collaborate across Europe. She noted how the United Kingdom can compare its performance with that of its neighbours and, by drawing on the diversity within Europe, we can discover more about the determinants of inequalities in health. In a clear break with the past, she made clear that Britain would henceforth play a full part in public health in Europe. The examples she cited illustrated this well. It would have been difficult to imagine her predecessors acknowledging publicly that we could learn from others with regard to the poor performance of the United Kingdom in preventing teenage pregnancy. In a telling remark, she said that British officials would no longer spend their time trying to get the term "inequalities" removed from international agreements.

There is also evidence of a new relationship with the European Parliament, with one member of the parliament noting that, for the first time, British MEPs were permitted to meet with officials of the English Department of Health. He observed that the Department's word processors seemed to have been reprogrammed to allow the word "Europe" to appear under solutions and not only under problems, as was the case under the previous government.

This new approach has potential implications for all of Europe. For years, the United Kingdom sought to block many European public health initiatives. In his speech, Pádraig Flynn, the European Social Affairs Commissioner, emphasised how important the change in British policy had been in bringing about a Europe wide ban on tobacco advertising.

So where does the United Kingdom now stand on public health in Europe? Tessa Jowell set out three principles. Firstly, while acknowledging the need to collaborate, it is still the governments of member states that are responsible for developing policies that improve health and deliver health care. Secondly, the European Union should concentrate on developing an infrastructure that would support policy analysis and, in particular, assessment of the impact on health of European Union policies in other fields, such as agriculture and transport. Thirdly, the most effective way forward is to ensure that the European Union makes full use of its policies in other areas to improve health and, most importantly, to ensure that these policies do not undermine the efforts of member states to develop healthy public policies. She also emphasised the need to take a long term view in public health, while also adopting intermediate, measurable goals.
But it is not only Britain that is changing. The Commission has also reassessed its activities in the field of public health. As Commissioner Flynn noted, many of the policies had developed piecemeal and do not provide the flexibility needed to tackle the health needs of the population of Europe, both current and emerging. The new approach proposed is set out in a recent Commission communication. ${ }^{1}$ It identifies the challenges facing the European Union as upward pressure on health care costs, aging populations, the introduction of new medical technology, how best to organise health systems, rising popular expectations, and European Union enlargement. To tackle these challenges the Commission argues that future European Union action should be based on three action strands: improving information for the development of public health; reacting rapidly to threats to health; and tackling health determinants through health promotion and disease prevention. The last of these indicates a broader perspective than that in the Amsterdam Treaty, which focuses on a narrow, disease based approach. ${ }^{2}$

The two speeches indicated considerable common ground, such as the need to ensure that health considerations feature in all European policies, although there also seems some room for debate, such as what, precisely, should be the limits to the European Union's competence in the area of health services. Furthermore, enthusiasm for measurable goals for health improvement, such as those set out in the World Health Organisation's Health for All policy and the United Kingdom green paper on public health, ${ }^{3}$ did not seem to be reflected in the Commission's communication. None the less, there now seems to be the goodwill that will be required to translate words into action.

After the politicians had spoken, the participants had their say. There was a general welcome for the new consensus that was emerging, but there was little evidence of complacency. The European Union's public health activities may be making progress but there are important challenges ahead. The collection and dissemination of information appropriate for evidence-based policy development in Europe remains weak, especially concerning the health impact of Community policies in other sectors, such as agriculture, environment, and transport. ${ }^{4}$ Support for public health research remains inadequate despite the potential for learning from the diversity of health in Europe. ${ }^{5}$ Public health leadership, advocacy, and training need to be strengthened.

These challenges have not been met adequately by the existing system but change has been difficult, not least because of the blocking tactics of several member states. The new found willingness of the United Kingdom to engage constructively with the European Union offers many opportunities for exploring how best to develop an effective European public health policy.

There seems to be widespread agreement that such a policy requires an enhanced public health capacity within the Commission and mechanisms that will facilitate better coordination both within the European Commission and between the Commission, member states, and international organisations. What is now needed is a debate on how the 
European Union institutions can best be structured to achieve these changes, for instance whether the time is now right for a new Directorate General for health.

ELIAS MOSSIALOS

London School of Economics and Political Science, London WC2A $2 A E$

MARTIN MCKEE ANNE-MARIE RAFFERTY

London School of Hygiene and Tropical Medicine, London WC1E 7HT

NOEL OLSEN
Correspondence to: Professor McKee.

1 Commission of the European Communities. Communication from the Commission on the development of public health policy in the European Community. COM (1998) 230 Final. Brussels: 1998.

2 Mossialos E, McKee M. The Amsterdam Treaty and the future of European health policy. F Health Serv Res Policy 1998;3:65-7.

3 United Kingdom Government. Our Healthier Nation. A Contract for Health (Cm 3854). London: HMSO, 1998.

4 BMA Board of Science and Education. Health and environmental impact assessment - an integrated approach. London: Earthscan, 1998.

British Medical Association, London WC1H $97 P$

5 McKee M. An agenda for public health research in Europe. Eur $7 \mathrm{Publ}$ Health 1998;8:3-7.

\section{JECH and the world wide web}

Visitors to the world wide web can now access the fournal of Epidemiology and Community Health either through the BMJ Publishing Group's home page (http://www.bmjpg.com) or directly by using its individual URL (http://www.jech.com). There they will find the following:

- Current contents list for the journal

- Contents lists of previous issues

- Members of the editorial board

- Subscribers' information

- Instructions for authors

- Details of reprint services.

Hotlink

A hot link gives access to:

- BMJ Publishing Group home page

- British Medical Association website

- Online books catalogue

- BMJ Publishing Group books.

Suggestions welcome

The website is at a preliminary stage and there are plans to develop it into a more sophisticated site. Suggestions from visitors about features they would like to see are welcomed. They can be left via the opening page of the BMJ Publishing Group site or, alternatively, via the journal page, through "about this site". 